\title{
ГЕНДЕРНІ ВІДМІННОСТІ ХАРАКТЕРУ ХАРЧУВАННЯ ХВОРИХ ПРАЦЕЗДАТНОГО ВІКУ З ОЖИРІННЯМ ТА АРТЕРІАЛЬНОЮ ГІПЕРТЕНЗІЄЮ*
}

\author{
Коваль С. М., Резнік Л. А., Старченко Т. Г., \\ Пенькова М. Ю., Мисниченко О. В. \\ ДУ «Національний інститут терапї̈ імені Л. Т. Малої НАМН Украӥни», \\ м. Харків, Україна \\ sergekovalmd@gmail.com
}

В сучасному світі проблема ожиріння набуває все більшого значення у зв'язку зі стрімким зростанням поширеності цієї патології $[1,2]$. Ожиріння, особливо, абдомінальне ожиріння (АО), е одним з основних факторів ризику серцево-судинних захворювань (СС3) i, в тому числі, артеріальної гіпертензії (АГ) [3, 4]. Крім того, в етіопатогенезі АО та АГ виділяються спільні фактори: генетичні $[5,6]$, нейро-гуморальні, гормональні, метаболічні та клітинні $[2$, $7,8]$. До ключових фракторів розвитку і АО, і АГ відносяться порушення норм здорового харчування з підвищенням калорійності і об'ему їжі $[4,8,9]$. Тому вирішальна роль у корекції ожиріння відводиться саме дієтичним втручанням, які необхідно проводити з урахуванням ряду показників, в тому числі, і гендерних особливостей харчування $[2,8,10]$. Однак даних літератури щодо гендерних відмінностей харчування хворих на $\mathrm{AO}$ з $\mathrm{AГ}$, особливо у працездатному віці, вкрай недостатньо.

В зв'язку з цим, метою даного дослідження було вивчення гендерних відмінностей характеру харчування хворих працездатного віку з абдомінальним ожирінням (АО) та артеріальною гіпертензіею (АГ) (мешканців України).

\section{МАТЕРІАЛИ ТА МЕТОДИ}

Обстежено 84 хворих на АО I-II ступеня у віці - 40-59 років (мешканці України). з АГ 2-3 ступеня (44 чоловіки і 40 жінок) Всім хворим проводили загально-клінічне

* Робота виконана в межах прикладної НДР Державної Установи «Національний інститут терапії імені Л. Т. Малої НАМН України» (м. Харків, Україна) «Розробити методи оптимізації лікування хворих на артеріальну гіпертензію з ожирінням на підставі вивчення гуморальних і епігенетичних факторів та параметрів мікробіоти кишечника» (№ госрегістрації 0120U000070).

Установою, що фінансує дослідження, е НАМН України.

Автори гарантують повну відповідальність за все, що опубліковано в статті.

Автори гарантують відсутність конфлікту інтересів і власної фінансової зацікавленості при виконанні роботи та написанні статті.

Рукопис надійшов до редакції 16.08.2021. 
обстеження. Діагностику АО проводили за критеріями ВООЗ та АTP III $[1,11]$, діагностику АГ та факторів ризику СС3 - за європейськими рекомендаціями [4]. Характер харчування хворих вивчали за допомогою аналізу анкети - «щоденника добового харчування», який заповнювався хворим на протязі 4-х діб. Відповідність добового раціону обстежених нормам здорового харчування оцінювали згідно сучасних європейських рекомендацій [4, 10] та Наказу МОЗ України № 1073 від 03.09.2017 р. [12] за наступними показниками: загальна енергетична цінність добового раціону, кількість та співвідношення споживаних білків, жирів ( в тому числі, насичених жирних кислот (НЖК) і транс-ненасичених жирних кислот (ТННЖК) та вуглеводів (в тому числі, моносахаридів (MC), кількість споживаних харчових волокон (ХВ), солі та алкогольних напоїв.

Отримані дані були проаналізовані 3 використанням комп'ютерної програми SPSS 19.0. для Windows XР. Оскільки отримана сукупність даних не відповідала критеріям нормального розподілу (критерієм Шапіро-Уілка), вони представлені у вигляді медіани і інтерквартільного інтервалу (Me [25\%; 75\%]). Відмінності вважалися статистично значущими при $\mathrm{p}<0,05$.

\section{РЕЗУЛЬТАТИ ТА ЇХ ОБГОВОРЕННЯ}

В результаті роботи встановлено, що загальна енергетична цінність добового раціону була достовірно вища у чоловіків $(3557,3$ [2623,5; 4114,8] ккал, p < 0,01) в порівнянні з жінками $(2782,4$ [2214,6; 3118,4] ккал). При цьому, загальна енергетична цінність добового раціону у $100 \%$ чоловіків i жінок перевищувала норму [12]. Однак, за показником добового розподілу їжі за калорійністю гендерної відмінності не виявлено: у більшості чоловіків (80\%) і жінок (73\%) максимальна енергетична цінність їжі припадала на вечерю ( $>$ > 0,05).

У обстежених чоловіків споживання жирів $(184,3$ [102,5; 262,4] г/на добу, р < 0,01) та їх внесок у загальну енергетичну цінність добового раціону - 47\%) був достовірно вищий, ніж у жінок (106,3 [87,9; 182,0] г/на добу) та 34\%, відповідно, p < 0,05). Також у 100\% чоловіків і жінок споживання жирів перевищувало норму [12]. Споживання вуглеводів у чоловіків і жінок достовірно не відрізнялось: (382,3 [314,6; 446,7] г/на добу) та (375,1 [302,4; 447,3] г/на добу), відповідно, p > 0,05. Однак у жінок на долю вуглеводів приходилось достовірно більша частка загальної енергетичної цінності добового раціону $(54 \%, \mathrm{p}<0,05)$, ніж у чоловіків (43\%). У $52 \%$ жінок і у $75 \%$ чоловіків споживання вуглеводів перевищувало норму [12]. Вміст білків у раціоні хворих був достатнім і гендерних відмінностей не виявлено.

Аналіз споживання ряду інших важливих компонентів харчування показав на- ступне: споживання НЖК у всіх чоловіків i жінок перевищувало норму $<10 \%$ від загальної енергетичної цінності добового раціону) [4], чоловіки споживали (86,3 [48,4; 119,2] г/на добу) НЖК, а жінки - (38,1 [32,9; 101,2] г/на добу), відповідно, $22 \%$ і $16 \%$ від загальної енергетичної цінності добового раціону. Споживання НЖК у чоловіків було достовірно вищим, ніж у жінок ( $p<0,01)$, але їх внесок у загальну енергетичну цінність добового раціону не відрізнявся ( $>$ > 0,05). Споживання ТННЖК у чоловіків $(11,3[4,5 ; 40,6]$ г/на добу) та у жінок $(5,6[1,5 ; 18,3]$ г /на добу) (3\% та $2 \%$ від загальної енергетичної цінності добового раціону) також перевищувало норму (< 1 \% від загальної енергетичної цінності добового раціону) [10], але гендерних відмінностей не виявлено.

Подібною до ТННЖК була і ситуація щодо MC: їх споживання у чоловіків $(155,2$ [92,2; 240,4] г/на добу) і у жінок (148,2 [64,2; $291,0]$ г/на добу) та внесок в загальну енергетичну цінність добового раціону (17\% i $21 \%$, відповідно) перевищували норму (< $10 \%$ від загальної енергетичної цінності добового раціону) [10], але гендерна різниця не виявлялась $(\mathrm{p}>0,05)$.

Достовірна відмінність $(\mathrm{p}<0,05)$ була встановлена у чоловіків і жінок за частотою звички «досолювати їжу» $(66 \%$ і $38 \%$, відповідно) та вживання алкоголю у помірних дозах (77\% і 55\%, відповідно). Осіб, які зловживали алкоголем не виявлено. 
З'ясування споживання ХВ показало, що цей показник був значно нижчий за норму (30-45 г на добу [10]) і у чоловіків (17,2 $[6,7 ; 24,2]$ г/на добу), і у жінок (28,8 [6,3; $38,4]$ г/на добу), проте жінки споживали достовірно більшу кількість ХВ, ніж чоловіки $(\mathrm{p}<0,05)$.

Таким чином, у хворих на $\mathrm{AO}$ з АГ, і у чоловіків, і у жінок, працездатного віку (мешканців України) встановлені суттеві порушення норм здорового харчування [10, 12]. Важливим результатом роботи є виявлення значних гендерних відмінностей у характері харчування хворих. Отримані дані щодо характеру харчування чоловіків хворих на $\mathrm{AO}$ з АГ в цілому знаходять підтвердження в опублікованій раніше роботі, в якій проводилось вивчення порушень харчування в аналогічній групі хворих (але більш широкого вікового діапазона 38-63 роки) в порівнянні з хворими на АГ без ожиріння [13].

Виходячи з результатів проведеної роботи, основними рекомендаціями щодо корекції харчування і у чоловіків, і у жінок хворих на $\mathrm{AO}$ з АГ можуть бути: зниження загальної енергетичної цінності добового раціону, перерозподіл добового раціону на першу половину доби, зниження вживання жирів, в тому числі, НЖК і ТННЖК, $\mathrm{MC}$ та підвищення споживання ХВ [10, 12]. Принципове значення для профілактики прогресування і АГ, і АО має роз'яснення хворим (особливо чоловікам) у необхідності відмови від «досолювання їжі», оскільки зловживання сіллю є одним 3 найважливіших фракторів патогенезу і АГ, і АО [2, 6]. Вкрай необхідне підвищення споживання ХВ (в ряді робіт доведено, що ХВ сприяють нормалізації порушень кишкової мікробіоти та зниженню ризику розвитку СС3, ожиріння і цукрового діабету 2 типу [4, 9, 10]. Що стосується алкоголю, то і чоловікам, і жінкам доцільно дотримуватись європейських рекомендацій щодо норм «здорової дієти» в частині вживання алкоголю [10].

Таким чином, результати роботи свідчать не тільки про необхідність своєчасного виявлення у хворих на АО з АГ гендерних особливостей характеру харчування, а й про важливість їх врахування при розробці індивідуалізованих підходів до корекції дієти у даних хворих.

\section{ВИСНОВКИ}

1. У чоловіків і жінок хворих на АО з АГ працездатного віку (мешканців України) встановлені суттеві порушення норм здорового харчування.

2. Встановлені значні гендерні відмінності характеру харчування хворих на АО з АГ: добовий раціон чоловіків достовірно відрізнявся від такого у жінок більшою енергетичною цінністю, більшим вмістом жирів, у тому числі, НЖК, та меншим вмістом ХВ. Крім того, чоловіки більш часто «досолювали їжу» та вживали алкоголь, ніж жінки.

3. Виявлені гендерні відмінності у характері харчування хворих на $\mathrm{AO}$ з АГ необхідно враховувати при виборі оптимального варіанту дієти як базового методу лікування даної категорії хворих.

\section{ЛITEPATУPA \\ (REFERENCES)}

1. WHO: Global Action Plan for the Prevention and Control of NCDs 2013-2020, available at: https://www. who.int/nmh/events/ncd_action_plan/en/.

2. Bays HE, McCarthy W, Burridge K, et al. Obesity Algorithm eBook, presented by the Obesity Medicine Association 2021, available at: https://obesitymedicine. org/obesity-algorithm.

3. Koval' S.M. Arterial'na Gipertenzija 2019; 1(63): 33-41.

4. Williams B, Mancia G, Spiering W, et al. Eur Heart $J$ 2018; 39(33): 3021-3104. http://doi.org/10.1093/eurheartj/ehy339.
5. Koval SM, Miloslavsky DK, Snegurska IA, et al. Probl Endokryn Patologii' 2020; 2: 44-50. http://doi.org/10. 21856/j-PEP.2020.2.05.

6. Williams B. Systemic hypertension. In.: The ESC Textbook of Cardiovascular Medicine. Third edition. Edited by: A. John Camm, Thomas F. Luscher, Gerald Mauer, Patrick W.Serruys. OXFORD University press, 2019: 2377-2478.

7. Koval' SM, Misnichenko OV, Pen'kova MJu. Probl Endokryn Patologii' 2020; 4: 60-65. http://doi.org/10.21856/jPEP.2020.4.07. 
8. Misjura KV, Mans'ka KG. Vestn Probl Biologii i Mediciny 2019; 1(153): 118-126. http://doi.org/10.29254/ 2077-4214-2019-4-1-153-118-126.

9. Fadjejenko GD, Isajeva GS, Rjeznik LA. Serce ta Sudyny 2016; 4: 104-109.

10. Piepoli MF, Hoes AW, Agewall S, et al. Eur Heart $J$ 2016; 37: 2315-2381. http://doi.org/10.1093/eurheartj/ ehw106.

11. Expert Panel of Detection, Evalution and Treatment of High Blood Cholesterol in Adults. Executive Summary of the Third Report of The National Cholesterol Education Program (NCEP) Expert (Adult treatment Panel III). JAMA 2001; 285(19): 2486-2497.

12. Normy fiziologichnyh potreb naselennja Ukrai'ny v osnovnyh harchovyh rechovynah i energii': Nakaz Ministerstva ohorony zdorov’ja Ukrai'ny № 1073 vid 03.09.2017.

13. Koval' SM, Reznik LA, Myloslavs'kyj DK. Probl Endokryn Patologii' 2020; 4: 66-70. http://doi.org/10.21856/jPEP.2020.4.08.

\title{
ГЕНДЕРНІ ВІДМІННОСТІ ХАРАКТЕРУ ХАРЧУВАННЯ ХВОРИХ ПРАЦЕЗДАТНОГО ВІКУ З ОЖИРІННЯМ ТА АРТЕРІАЛЬНОЮ ГІПЕРТЕНЗІЄЮ
}

\author{
Коваль С. М., Резнік Л. А., Старченко Т. Г., \\ Пенькова М. Ю., Мисниченко О. В. \\ ДУ «Національний інститут терапії імені Л. Т. Малої НАМН України», \\ м. Харків, Україна \\ sergekovalmd@gmail.com
}

Мета: вивчення гендерних відмінностей характеру харчування хворих працездатного віку з абдомінальним ожирінням (АО) та артеріальною гіпертензією (АГ) (мешканців України).

Матеріали і методи. Обстежено 84 хворих на АО I-II ступеня з АГ 2-3 ступеня (44 чоловіки і 40 жінок) у віці - 40-59 років (мешканців України). Характер харчування хворих вивчали за допомогою аналізу анкети - «щоденника добового харчування». Статистична обробка даних проведена за допомогою комп'ютерної програми SPSS 19.0. для Windows XP.

Результати. У хворих працездатного з АО та АГ - і у чоловіків, і у жінок (мешканців України) виявлені суттєві порушення норм здорового харчування: перевищення загальної енергетичної цінності добового раціону, порушення фізіологічного добового розподілу їжі за їі калорійністю, підвищення споживання жирів та вуглеводів, насичених жирних кислот, транс-ненасичених жирних кислот, моносахаридів, солі та алкоголю на тлі значного зменшення споживання харчових волокон. Встановлено, що добовий раціон у чоловіків достовірно відрізнявся від такого у жінок більш високою енергетичною цінністю, більшим вмістом жирів, у тому числі, насичених жирних кислот, та меншим вмістом харчових волокон. Чоловіки також більш часто «досолювали їжу» та вживали алкоголь, ніж жінки.

Висновки. Встановлені значні гендерні відмінності характеру харчування хворих працездатного з АО та АГ, які необхідно враховувати при корекції діети у даної категорії хворих.

Ключові слова: абдомінальне ожиріння, артеріальна гіпертензія, характер харчування, гендерні відмінності.

\section{GENDER DIFFERENCES IN THE NATURE OF NUTRITION IN PATIENTS OF WORKING AGE WITH OBESITY AND ARTERIAL HYPERTENSION}

Koval S. M., Rieznik L. A., Starchenko T. G., Penkova M. Yu., Mysnychenko O. V.

GI "L. T. Malaya Therapy National Institute of the NAMS of Ukraine», Kharkiv, Ukraine sergekovalmd@gmail.com

The aim: to study the gender differences in the nature of nutrition in patients of working age with abdominal obesity (AO) and arterial hypertension (AH) (residents of Ukraine).

Materials and methods. We examined 84 patients with I-II degrees AO and with 2-3 degrees II AH (44 men and 40 women) at the age of 40-59 years (residents of Ukraine). The dietary habits of the patients were studied by analyzing the "daily dietary diary» questionnaires. Statistical data processing was carried out using the SPSS 19.0. computer program for Windows XP.

Results: In patients of working age with $\mathrm{AO}$ and $\mathrm{AH}$-both men and women (residents of Ukraine), significant violations of the norms of healthy nutrition were revealed: an excess of the total energy value of the daily diet, a violation of the physiological daily distribution of food by its calorie content, an increase in the consumption of fat and carbohydrates, saturated fatty acids, trans-unsaturated fatty acids, monosaccharides, salt and 
alcohol against the background of a significant decrease in dietary fiber intake. It was found that the daily diet of men significantly differed from that of women in higher energy value, higher fat content, including saturated fatty acids, and lower dietary fiber content. Men also more frequently "added salt» and consumed alcohol than women. Conclusions: Significant gender differences in the nutritional pattern of patients of working age with $\mathrm{AO}$ and $\mathrm{AH}$ have been established, which must be taken into account when correcting the diet in this category of patients.

Keywords: arterial hypertension, abdominal obesity, the nature of nutrition, gender differences.

Коваль Сергій Миколайович, ORCID https://orcid.org/0000-0002-8699-2324

Резнік Лариса Аркадї̈вна, ORCID https://orcid.org/ 0000-0001-5200-3447

Старченко Тетяна Григорівна, ORCID https://orcid.org/0000-0003-1276-3868

Пенькова Марина Юрївна, ORCID https://orcid.org/0000-0003-4997-5936

Мисниченко Ольга Владиславівна, ORCID https://orcid.org/0000-0002-7577-2545 